\title{
Extranodal Marginal Zone Lymphoma of Mucosa-Associated Lymphoid Tissue
}

National Cancer Institute

\section{Source}

National Cancer Institute. Extranodal Marginal Zone Lymphoma of Mucosa-Associated Lymphoid Tissue. NCI Thesaurus. Code C3898.

An indolent, extranodal type of non-Hodgkin lymphoma composed of small Blymphocytes (centrocyte-like cells). The gastrointestinal tract is the most common site of involvement. Other common sites of involvement include lung, head and neck, ocular adnexae, skin, thyroid, and breast. Gastric involvement is associated with the presence of H. pylori infection. (WHO, 2001) 